\title{
Anti-mycoplasma activity of Curcuma longa extracts and an isolated compound, the curcumin
}

DOI 10.5935/2446-4775.20180010

Boeder, Ariela Maína ${ }^{1}$; Tenfen, Adrielli³; Siebert, Diogo Alexandre²; Almeida, Camila Leandra de Bueno ${ }^{4}$; Firmo, Cláudia Rafaela Marques; ${ }^{4}$ Scharf, Dilamara Riva ${ }^{5}$; Micke, Gustavo Amadeu ${ }^{6}$; Siminionatto, Edésio Luís ${ }^{4}$; Cordova, Caio Mauricio Mendes de $^{4}$; Guedes, Alessandro ${ }^{4}$.

${ }^{1}$ Universidade Federal de Santa Catarina, Centro de Ciências Biológicas, Laboratório de Genética do Comportamento, BEG, bloco C, $3^{\circ}$ andar, Córrego Grande, CEP:88037-000, Florianópolis, SC, Brasil.

${ }^{2}$ Universidade Federal de Santa Catarina, UFSC, Departamento de Química, Campus Trindade, Rua Reitor João David Ferreira Lima, s/nº, CEP: 88040-900, Florianópolis, SC, Brasil.

${ }^{3}$ Instituto Educacional de Santa Catarina, Faculdade Jangada, Departamento de Ciências Farmacêuticas, Rua Presidente Epitácio Pessoa, 676, Centro, CEP: 89251-100, Jaraguá do Sul, SC, Brasil.

${ }^{4}$ Fundação Universidade Regional de Blumenau - FURB, Departamento de Ciências Farmacêuticas, Campus 3, Rua São Paulo - de 924 ao fim - Itoupava Seca, CEP: 89030-001, Blumenau, SC, Brasil.

${ }^{5}$ Fundação Universidade Regional de Blumenau, Laboratório de Cromatografia, Rua São Paulo, 3250, Itoupava Seca, CEP: 89030000, Blumenau, SC, Brasil.

${ }^{6}$ Universidade Federal de Santa Catarina, Centro de Ciências Físicas e Matemáticas, Departamento de Química, laboratório 313, Rua Roberto Sampaio Gonzaga, s/nº, Campus Trindade, CEP: 88040900, Florianópolis, SC, Brasil.

*Correspondência: ariela.qs@hotmail.com

\begin{abstract}
Curcuma longa (saffron) is widely used in Western cuisine and its consumption is associated to the prevention and control of various diseases. Nevertheless, there no report on its antibacterial activity against mycoplasma strains. Thus, the present study aims to evaluate the antibacterial activity of $C$. longa and the curcumin against strains of mycoplasma. The rhizomes of $C$. longa were submitted to different processes of conservation followed by maceration to obtain ethanolic and acetonic extracts, and decoction to obtain aqueous extracts. The extracts were analyzed by high-performance liquid chromatography coupled to an ultraviolet detector (HPLC-UV) to quantify curcumin. Anti-mycoplasma activity of the extracts and curcumin were evaluated using a broth microdilution technique to determine the minimum inhibitory concentration (MIC). The best activity was observed in the ethanolic and acetonic extracts, which had the higher curcumin content, indicating a relationship between the presence of this compound and the anti-mycoplasmatic activity.
\end{abstract}

Keywords: Curcuma; Curcumin; Anti-bacterial activity; Mycoplasma. 


\section{Introduction}

The Mycoplasmas are part of the Mollicutes class, a large group of peculiar microorganisms responsible for a series of diseases in animals, plants and in humans, being notable for causing sexually transmitted diseases (STDs) and respiratory infections ${ }^{(1)}$. These microorganisms are capable of self-replication (2), whose major phenotypic characteristics are the absence of cell wall and its reduced genome (쯔). Additionally, a significantly increased incidence of infections, more likely in immunocompromised patients, causing opportunistic infections associated with acquired immunodeficiency syndrome (AIDS), cancer chemotherapy and transplantation.

Due to the absence of cellular wall, mycoplasmas are just susceptible for a few antimicrobial agents such macrolides, tetracyclines and quinolones (4). The identification of new antimicrobials from plants can be of great contribution in the fight against these infections $(\underline{5})$.

The Curcuma longa, popularly known as turmeric, golden ginger and earth's saffron, belongs to the family Zingiberaceae ( $(\underline{6})$. Widely used as a spice, food conservative and dye material. In traditional medicine is used for disease control, due to its anti-oxidant, anti-inflammatory, antifungal and anti-carcinogenic activities. The curcumin, a curcuminoid, is the main bioactive yellow component of turmeric and is the responsible for the broad spectrum of biological actions of this plant ${ }^{(7)}$. Nevertheless, there was no report on its antibacterial activity against mycoplasma strains.

Thus, the objective of this study was to evaluate the anti-mycoplasma activity of Curcuma longa and its main compound (curcumin) against species of Mycoplasma hominis, Mycoplasma capricolum, Mycoplasma genitalium, Mycoplasma mycoides subsp. Capri, Mycoplasma pneumoniae strains FH and 129.

\section{Material and Methods}

Plant material: The rhizomes of $C$. longa were collected in Blumenau (SC, Brazil), identified by the botanist André Luiz Gasper, and a voucher specimen was deposited in the Dr. Roberto Miguel Klein herbarium, from Universidade Regional de Blumenau (FURB), under the number 46859.

Preparation of plant material: Samples of rhizomes $(50 \mathrm{~g})$ were submitted to different thermal processes to evaluate the best method of conservation of the main constituent of the plant, curcumin. Thus, three ethanolic extracts were prepared, process 1 : rhizomes were frozen at $-18^{\circ} \mathrm{C}$ for six months and extracted with $96 \%$ ethanol (EFH); process 2: rhizomes were stored away from light for six months and extracted with 96\% ethanol (ESL); process 3: rhizomes in natura extracted after collection with $96 \%$ ethanol (EIH).

Then, the best extractive solvent for the curcuminoid compounds was evaluated using samples (50 g) oven-dried rhizomes at $60^{\circ} \mathrm{C}$ were extracted with 3 different solvents: $96 \%$ ethanol (EID), acetone (KID) and water (AID).

Extraction procedure: To obtain ethanolic (EtOH 96\%) and acetonic extracts, rhizomes were crushed in a turbolizer and macerated with shaking for 4 hours. The extracts were subjected to filtration and concentrated on a rotary evaporator under reduced pressure to constant weight. 
To obtain the aqueous extract the rhizomes were crushed, macerated and extracted by decoction at $90^{\circ} \mathrm{C}$ for 10 minutes, mimicking the popular use in the form of tea. After filtration, the extracts were frozen at $-18^{\circ} \mathrm{C}$ for 24 hours and lyophilized for 72 hours to constant weight.

Chromatographic analysis of curcumin: The chromatographic analysis was performed (). Individual standard solutions and the extract were prepared by dissolving $5 \mathrm{mg}$ of each in $10 \mathrm{~mL}$ of methanol to obtain a stock solution of $500 \mathrm{mg} / \mathrm{L}$. Calibration curve was prepared with concentrations ranging from 0,2 to $100 \mathrm{mg} / \mathrm{L}$ by diluting the curcuminoid stock solution in methanol.

All chromatographic analyses were carried out using an Agilent 1260 infinity, using an Agilent Eclipse Plus C18 (4,6 i.d. x $150 \mathrm{~mm} ; 5 \mu \mathrm{m})$ column, set at $25^{\circ} \mathrm{C}$. The eluents were formed by mixing solvents, $\mathrm{A}\left(\mathrm{H}_{2} \mathrm{O}\right.$ ultrapure/acetic acid $1 \%$ ) and B (acetonitrile) as follows: $1^{\text {st }}$ stage - linear gradient of solvents A and B (from 45 to $50 \%$ of $A$ ) for 6 minutes; $2^{\text {nd }}$ stage - linear gradient of solvents $A$ and $B$ (from 50 to $45 \%$ of $A$ ) for 1 minute; $3^{\text {rd }}$ stage $-45 \%$ of solvent $A$ and $55 \%$ B (isocratic mode) for 3 minutes with a flow rate of $1 \mathrm{~mL} / \mathrm{min}$ of mobile phase. In all analysis, the injected volume was $5 \mathrm{uL}$. The DAD was set at $424 \mathrm{~nm}$ (at $4 \mathrm{~nm}$ bandwidth). Full spectral scanning was also performed from 190 to $600 \mathrm{~nm}$, with a range step of $2 \mathrm{~nm}$. Agilent Chem Station software was used to control all analytical conditions and data acquisition. Sample quantification was calculated by comparing peak area with the external calibration curve from neat standard solution.

Anti-mycoplasma activity: To evaluate the anti-mycoplasma activity the minimum inhibitory concentration (MIC) was determined by the broth microdilution method, in 96-well plates as indicated by the CLSI (ㅁ) with slight modifications $\stackrel{(10)}{ }$. The microorganisms used were strains standardized of Mycoplasma hominis (ATCC 23114) in Arginine liquid medium (MLA), Mycoplasma capricolum (ATCC 27343), Mycoplasma genitalium (ATCC 33530), Mycoplasma pneumoniae strains FH (ATCC 15531) and 129 (ATCC 29342), as well as strain of Mycoplasma mycoides subsp. capri (NCTC 10137) in liquid medium SP4 (specific for Mycoplasmas) stored at $-20^{\circ} \mathrm{C}$.

Subcultures were prepared by withdrawing $1 \mathrm{ml}$ of a stock culture from each growth log strain, which was added to a sterile Falcon-type tube containing $9 \mathrm{ml}$ of culture medium and incubated at $36^{\circ} \mathrm{C} \pm 1{ }^{\circ} \mathrm{C}$ for 2 hours in microaerophilic $(2-3 \% \mathrm{CO} 2)$. After this incubation period, the cultures diluted at $104 \mathrm{CFU} \mathrm{mL}^{-1}$ (colony-forming units) were used in the MIC tests. The crude extracts were diluted to $40 \mathrm{mg} \mathrm{mL}^{-1}$ and the isolated compounds diluted to $4 \mathrm{mg} \mathrm{mL}^{-1}$ in dimethylsulfoxide (100\% DMSO), the samples was performed serial diluition of order 2 and added inoculum of the cultures of molicutes in all wells. As growth control, a serial dilution of the culture of the microorganism was performed without the addition of solvent or extract; as a positive control the antibiotic azithromycin (DME ${ }$, Araçatuba, Brazil); as a negative control a serial dilution of the solvent itself (100\% DMSO, without the presence of extract); as control of the culture medium, only medium; as control of sterility of the extracts and fractions a cavity was reserved for each sample plus the culture medium.

The plates were incubated at $37^{\circ} \mathrm{C}$ for the time required for each strain ( $24 \mathrm{~h}$ to 30 days), and growth is observed from the change in staining of the culture medium due to the presence of the red phenol $\mathrm{pH}$ indicator. 


\section{Results and discussion}

For evaluation purposes of curcumin content in the different prepared extracts, the samples were submitted to HPLC-UV analysis (TABLE 1). Analyzing the results, it was concluded that the best way of conserving curcumin is to leave the stored rhizomes sheltered from the light in room temperature for 6 months (ESL), which presented a curcumin content of the 5,71\%. Storing the tubers under the shelter of light conserves the content of curcumin, as evidenced in this work $(\underline{11})$. These results are probably due to the photosensitive characteristic of turmeric $\underline{(12)}$.

Comparing the extractive capacity of the three used solvents (ethanol, acetone and water) the results indicated that ethanolic (EID) and acetonic (KID) extracts present higher levels of curcumin, 3,63\% and 3,5\% respectively. In addition, the aqueous extracts obtained the lowest levels of curcumin $(0,16 \%)$. These results agree to literature, and are mainly related to the solubility of curcumin, which is better in ethanol and acetone $\left.{ }^{(13}\right)$.

TABLE 1: Curcumin dosing of the extracts.

\begin{tabular}{c|c|c}
\hline Analysis & Extracts & Curcumin content (\%) $^{\mathbf{a}}$ \\
\hline & ESL & 5,71 \\
\hline Conservation & EFH & 2,92 \\
\hline & EIH & 0,62 \\
\hline Solvents & EID & 3,63 \\
\hline & KID & 3,5 \\
\hline
\end{tabular}

Legend: aCalculated in g/100g; ESL = Ethanolic to the Shelter of Light; EFH = Ethanolic Frozen Humid; EIH = Ethanolic In natura Humid; EID = Ethanolic In natura Desiccated; KID = Acetonic In natura Desiccated; AID = Aqueous In natura Desiccated.

There are several studies that attribute antibacterial activity to $C$. longa (6) as well as curcumin (14). However, this is the first work that evaluates the antibacterial activity of $C$. longa and curcumin against bacteria without cell wall (TABLE 2).

TABLE 2: Anti-mycoplasma activity of the extracts and curcumin.

\begin{tabular}{|c|c|c|c|c|c|c|}
\hline \multirow[b]{2}{*}{ Samples } & \multicolumn{6}{|c|}{ Minimal Inhibitory Concentration $\left(\mu \mathrm{g} \mathrm{mL}^{-1}\right)$} \\
\hline & $\begin{array}{c}M . \\
\text { hominis }\end{array}$ & $\begin{array}{c}\text { M. } \\
\text { capricolum }\end{array}$ & $\begin{array}{c}\text { M. } \\
\text { mycoides } \\
\text { subsp. } \\
\text { capri }\end{array}$ & M. genitalium & $\begin{array}{c}\text { M. pneumonie } \\
\text { FH }\end{array}$ & $\begin{array}{c}\text { M. Pneumonie } \\
129\end{array}$ \\
\hline ESL & 125 & 500 & 250 & 125 & 250 & 125 \\
\hline $\mathrm{EFH}$ & 125 & 250 & 250 & 125 & 125 & 500 \\
\hline $\mathrm{EIH}$ & 1000 & $>1000$ & $>1000$ & 1000 & 1000 & 500 \\
\hline EID & 125 & 500 & 250 & 125 & 250 & 125 \\
\hline KID & 125 & 125 & 125 & 125 & 125 & 125 \\
\hline AID & $>1000$ & $>1000$ & $>1000$ & $>1000$ & $>1000$ & $>1000$ \\
\hline Curcumin & 50 & 50 & 100 & 50 & 50 & 100 \\
\hline Control $+{ }^{b}$ & 2 & 2 & 2 & 2 & 2 & 2 \\
\hline
\end{tabular}

Legend: ${ }^{\mathrm{b} C o n t r o l}+=$ Azitromicin; ESL = Ethanolic to the Shelter of Light; $\mathrm{EFH}=$ Ethanolic Frozen Humid; EIH = Ethanolic In natura Humid; EID = Ethanolic In natura Desiccated; KID = Acetonic In natura Desiccated; AID = Aqueous In natura Desiccated. 
The extracts were analyzed by the criteria established $\left.{ }^{(15}\right)$ which determines that samples with MIC values below $10 \mu \mathrm{g} \mathrm{mL}^{-1}$ are considered to have excellent antibacterial activity; Values between 10 and $100 \mu \mathrm{g} \mathrm{mL}$ ${ }^{1}$ are considered good; Values between 100 and $500 \mu \mathrm{g} \mathrm{mL} \mathrm{L}^{-1}$ are considered moderate activity; Values between 500 and $1000 \mu \mathrm{g} \mathrm{mL}^{-1}$ of weak activity, and the samples are considered inactive for MIC values above $1000 \mu \mathrm{g} \mathrm{mL}^{-1}$. For the isolated compounds values above $100 \mathrm{ug} \mathrm{mL} \mathrm{L}^{-1}$ were considered inactive for Mycoplasmas.

The acetones and ethanolic extracts had better anti-mycoplasma activity. When related with the curcumin content was observed that samples with curcumin content greater than 2.5\% showed the best results, like ESL with MIC of $125 \mu \mathrm{g} \mathrm{ml}^{-1}$ against M. hominis, M. genitalium and M. pneumoniae 129, and KID with MIC of $125 \mathrm{\mu g} \mathrm{ml}^{-1}$ against all the strains. On the other hand, it is possible to observe that the aqueous extract with lower curcumin content, was considered inactive (MIC $\left.>1000 \mu \mathrm{g} \mathrm{m}^{-1}\right)^{(15)}$.

In addition, it was evaluated that the MIC of curcumin being considered good activity for an isolated compound ( $\mathrm{MIC}=50 \mu \mathrm{g} \mathrm{ml}^{-1}$ against $M$. hominis, $M$. capricolum, $M$ genitalium and $M$. pneumoniae $\mathrm{FH}$ ).

A study was conducted ${ }^{(16)}$ to evaluating an antibacterial activity of curcumin against cell wall bacteria such as methicillin-sensitive Staphylococcus aureus (MSSA), methicillin-resistant Staphylococcus aureus (MRSA), Enterococcus faecalis, Bacillus subtilis, Pseudomonas aeruginosa, Escherichia coli and Klebsiella Pneumoniae, where curcumin showed activities as MIC strains ranging from $129 \mathrm{mg} \mathrm{ml}^{-1}$ to $293 \mathrm{mg} \mathrm{ml}^{-1}$. Another study found out affirm that the antibacterial activity presented by curcumin against Bacillus subtilis and Escherichia coli occurs due to the inhibition of FtsZ polymerization (17). The FtsZ cytoskeletal protein plays a key role in prokaryotic cell division and is present in most bacterial species. The mycoplasma has more components of the division cellular being this protein responsible for one of them $(\underline{18})$. This way, the inhibition of mycoplasmas growth by curcumin, evidenced in this work, may have occurred due to the inhibition of this protein, which also exists in this class of microorganisms.

\section{Conclusion}

In conclusion, it is possible to affirm that to obtain higher levels of curcumin it is necessary to use solvents like ethanol and acetone, and it was proved that the storage of the vegetal material conserves the content of curcumin. In addition, the $C$. longa has good activity against Mycoplasma strains and a minimum concentration of curcumin is need for a sample to become active, making the $C$. longa an important source of study for future. In addition, this work assists in the verification of another important biological activity for C. longa.

\section{References}

1. Razin S, Yogev D, Naot Y. Molecular biology and pathogenicity of mycoplasmas. Microbiol Mol Biol Rev. 1998; 62 (4): 1094-1156. [PubMed].

2. Cordova CMM, Cunha RAF. Detecção de Mycoplasma genitalium, M. fermentans e M. penetrans em pacientes com sintomas de uretrite e em indivíduos infectados pelo HIV-1 no Brasil. J Bras Patol Med Lab. 2002; 38 (2): 119-126. ISSN: 1678-4774. [CrossRef]. 
3. Santos SB, Nascimento ER, Faccini JLH, Barreto ML, Almeida JF, Pereira VLA, et al. Detenção do Grupo Mycoplasma mycoides por imunoperoxidase indireta (IPI) e PCR-REA em conduto auditivo de bovinos. Pesq. Vet. Bras. 2010; 30 (5): 465-469. [Link].

4. Taylor-Robinson D, Bébéar C. Antibiotic susceptibilities of mycoplasmas and treatment of mycoplasmal infections. J Antimicrob Chemother. 1997; 40 (5): 622-630. [CrossRef][PubMed].

5. Cordova SM, Benfatti CS, Magina MDA, Guedes A, Cordova CMM. Evaluation of the antibacterial activity of extracts isolated from native plants of the Brazilian flora against Mycoplasma arginini, M. hominis and Ureaplasma urealyticum. RBAC. 2014; 42 (4): 241- 244. [Link].

6. Péret-Almeida L, Naghetini CDC, Nunan EDA, Junqueira RG, Glória MBA. Atividade antimicrobiana in vitro do rizoma em pó, dos pigmentos curcuminóides e dos óleos essenciais da Curcuma longa L. Ciênc Agrotec. 2008; 32 (3): 875-881. ISSN: 1413-7054. [CrossRef].

7. Prasad S, Gupta SC, Tyagi AK, Aggarwal BB. Curcumin, a component of golden spice: From bedside to bench and back. Biotechnol Adv. 2014; 32 (6): 1053-1054. [CrossRef].

8. Kim Y, Lee HJ, Shin Y. Optimization and validation of high-performance liquid chromatography method for individual curcuminoids in turmeric by heat-refluxed extraction. J Agric Food Chem. 2013; 61(46): 10911-10918. [CrossRef] [PubMed].

9. CLSI. Methods for dilution antimicrobial susceptibility tests $f$ or bacteria that grow aerobically. Wayne, PA: Clinical and Laboratory Standards Institute. Ninth Edittion. 2012. CLSI document M97-A9.

10. Bebear C, Robertson J. Determination of the minimal inhibitory concentration. In: Tully JG, Razin S, editors. Molecular and diagnostic procedures in mycoplasmology. San Diego: Academic Press; 1996. p. 189-197.

11. Ganpati KS, Bhaurao SS, Iranna KK, Dilip CR, Nilkanth YP. Comparative studies on curcumin content in fresh and stored samples of turmeric rhizomes. IRJP. 2011; 2 (4): 127-129. ISSN: 2230-8407. [Link].

12. Sogi DS, Sharma S, Oberoi DPS, Wani, IA. Effect of extraction parameters on curcumin yield from turmeric. J Food Sci Technol. 2010; 47 (3): 300-304. [CrossRef].

13. Himesh S, Sharan OS, Mishra K, Govind N, Singhai AK. Qualitative and quantitative profile of curcumin from ethanolic extract of Curcuma longa. IRJP. 2011; 2 (4): 180-184. ISSN: 2230-8407. [Link].

14. Mun SH, Joung DK, Kim YS, Kang OH, Kim SB, Seo YS, et al. Synergistic antibacterial effect of curcumin against methicillin-resistant Staphylococcus aureus. Phytomedicine. 2013; 20 (8-9): 714-718. [CrossRef] [PubMed].

15. Holetz FB, Penssini GL, Sanches NR, Cortez DAG, Nakamura C, Dias-filho BP. Screening of some plants used in the Brazilian folk medicine for the treatment of infectious diseases. Mem Inst Oswaldo Cruz. 2002; 97 (7):1027-1031. [CrossRef] [PubMed]. 
16. Gunes H, Gulen D, Mutlu R, Gumus A, Tas T, Topkaya AE. Antibacterial effects of curcumin: an in vitro minimum inhibitory concentration study. Toxicol Ind Health. 2016; 32 (2): 246-250. [CrossRef] [PubMed].

17. Kaur S, Modi NH, Panda D, Roy N. Probing the binding site of curcumin in Escherichia coli and Bacillus subtilis FtsZ-a structural insight to unveil antibacterial activity of curcumin. Eur J Med Chem. 2010; 45 (9): 4209-4214. [CrossRef] [PubMed].

18. Vaughan S, Wickstead B, Gull K, Addinall SG. Molecular evolution of FtsZ protein sequences encoded within the genomes of archaea, bacteria, and eukaryota. J Mol Evol. 2004; 58 (1): 19-29. ISSN: 1432-1432. [CrossRef] [PubMed].

Conflito de interesses: O presente artigo não apresenta conflitos de interesse.

Histórico do artigo: Submissão: 20/01/2018 | Aceite: 25/05/2018 | Publicação: 05/07/2018

Como citar este artigo: Boeder AM, Tenfen A, Siebert DA, Almeida CLB, Firmo CRM, Scharf DR, Micke GA, Siminionatto EL, Cordova CMM, Guedes A. Anti-mycoplasma activity of Curcuma longa extracts and your isolated compound, the curcumin. Rev Fitos. Rio de Janeiro. 2018; 12(2): 110-116. e-ISSN 2446.4775. Disponível em: <http://revistafitos.far.fiocruz.br/index.php/revista-fitos/article/view/601>. Acesso em: dd/mm/aaaa.

Licença CC BY 4.0: Você está livre para copiar e redistribuir o material em qualquer meio; adaptar, transformar e construir sobre este material para qualquer finalidade, mesmo comercialmente, desde que respeitado o seguinte termo: dar crédito apropriado e indicar se alterações foram feitas. Você não pode atribuir termos legais ou medidas tecnológicas que restrinjam outros autores de realizar aquilo que esta licença permite. 